\title{
PENGEMBANGAN MODEL PEMBELAJARAN SOFT SKILLS TERPADU DALAM PEMBELAJARAN PENJASORKES PADA SEKOLAH MENENGAH PERTAMA
}

\author{
${ }^{1)}$ Lilik Indriharta, ${ }^{2)}$ Suharjana, ${ }^{3)}$ Marzuki \\ ${ }^{1)}$ UPN Veteran Yogyakarta, ${ }^{2,3)}$ Universitas Negeri Yogyakarta \\ liliktrail@gmail.com, suharjana_fikuny@yahoo.com,marzuki@uny.ac.id
}

\begin{abstract}
Abstrak
Tujuan penelitian ini adalah untuk: (1) mengembangkan model pembelajaran soft skills terpadu, (2) menganalisis keberhasilan pelaksanaan pembelajaran soft skills terpadu, dan (3) menganalisis dampak penerapan model pembelajaran Soft Skills Terpadu dalam pembelajaran Penjasorkes di Sekolah Menengah Pertama terhadap siswa. Penelitian ini merupakan penelitian pengembangan (Research \& Development). Subjek uji coba dalam penelitian ini adalah kelas VII pada 4 SMP Negeri di Kota Yoyakarta. Analisis data dilakukan secara deskriptif kualitatif dan kuantitatif. Hasil penelitian menunjukkan bahwa: (1) Tahap pengembangan model pembelajaran soft skills terpadu dalam pembelajaran Penjasorkes adalah tahap pendahuluan, pengembangan, dan evaluasi dengam hasil perangkat model berupa buku panduan, perangkat penilaian, dan instrumen pengembangan model pembelajaran. (2) Model pembelajaran soft skills terpadu dalam pembelajaran Penjasorkes menunjukkan tingkat keterlaksanaan yang tergolong sangat baik, memenuhi kriteria valid, sangat efektif, dan sangat praktis. (3) Model pembelajaran Soft Skills Terpadu dalam pembelajaran Penjasorkes di Sekolah Menengah Pertama mampu mengembangkan soft skills siswa.
\end{abstract}

Kata kunci: model pembelajaran soft skills terpadu, pembelajaran pendidikan jasmani, olahraga, dan kesehatan, sekolah menengah pertama

\section{DEVELOPING INTEGRATED SOFT SKILLS LEARNING MODEL IN PHYSICAL EDUCATION, SPORT, HEALTH, AND RECREATION INSTRUCTION IN JUNIOR HIGH SCHOOL}

\author{
${ }^{1)}$ Lilik Indriharta, ${ }^{2}$ Suharjana, ${ }^{3)}$ Marzuki \\ ${ }^{1)}$ UPN Veteran Yogyakarta, ${ }^{2,3}$ Universitas Negeri Yogyakarta \\ liliktrail@gmail.com, suharjana_fikuny@yahoo.com,marzuki@uny.ac.id
}

\begin{abstract}
This research is aimed at: (1) developing integrated soft skills learning model, (2) analyzing the success of integrated soft skills learning model implementation, and (3) analyzing the impact of the implementation of integrated soft skills learning model in physical education, sport, health, and recreation instruction on the students of junior high school. The research was a research adn development $(R \& D)$. The subject of the research was students of grade VII in four junior high schools in Yogyakarta Municipality. Data analysis was conducted using qualitative and quantitative descriptive method. The result of the research shows that: (1) The stages of developing integrated soft skills learning model in physical education, sport, health, and recreation instruction include the stages of introduction, development, and evaluation which results model set in the form of handbook, assessment set, and instrument of learning model development. (2) Integrated soft skills learning model in physical education, sport, health, and recreation instruction reveals a very good level of implementation, fulfills the 'valid' citerion, is very effective and also practical. (3) Integrated soft skills learning model in physical education, sport, health, and recreation instruction in junior high school is capable to develop students' soft skills.
\end{abstract}

Keywords: integrated soft skills learning model; physical education, sport, health, and recreation instruction; junior high school 



\section{PENDAHULUAN}

Revitalisasi Dalam kondisi bangsa Indonesia yang seperti sekarang ini, pengembangan soft skills menjadi mutlak diperlukan. Istilah yang mengemuka di Negara Indonesia beberapa waktu terakhir mengenai revolusi mental tentunya sangat erat kaitannya dengan pendidikan. Pendidikan dapat dijadikan sebagai suatu wahana atau media yang digunakan dalam pelaksanaan revolusi mental. Kementerian Koordinator Bidang Pembangunan Manusia dan Kebudayaan (2015, p. 1) menjelaskan bahwa revolusi mental merupakan suatu gerakan seluruh masyarakat (pemerintah dan rakyat) dengan cara yang cepat untuk mengangkat kembali nilai-nilai strategis yang diperlukan oleh bangsa dan negara untuk mampu menciptakan ketertiban dan kesejahteraan rakyat sehingga dapat memenangkan persaingan di era globalisasi. Revolusi mental ditujukan untuk mengubah cara pandang, pikiran, sikap, perilaku yang berorientasi pada kemajuan dan kemodernan, sehingga Indonesia menjadi bangsa besar dan mampu berkompetisi dengan bangsa-bangsa lain di dunia.

Revolusi mental sebenarnya bukanlah hal baru bagi bangsa Indonesia. Istilah ini sudah bermula dari gagasan yang dicetuskan oleh Presiden Soekarno pada tahun 1957. Presiden Soekarno pernah menyatakan bahwa "Revolusi Mental merupakan satu gerakan untuk menggembleng manusia Indonesia agar menjadi manusia baru, yang berhati putih, berkemauan baja, bersemangat elang rajawali, berjiwa api yang menyala-nyala" (Kementrian Koordinator Bidang Pembangunan Manusia dan Kebudayaan, 2015, p. 3). Seiring dengan berjalannya waktu, revolusi mental tidak lagi menjadi perhatian bangsa Indonesia yang sedang giat melaksanakan pembangunan. Sampai dengan saat ini, ketika dihadapkan pada 3 masalah pokok bangsa maka revolusi mental kembali dianggap sebagai salah satu jalan untuk menyelesaikan segala persoalan yang kompleks terjadi. Adapun ketiga masalah pokok bangsa tersebut adalah merosotnya wibawa negara, lemahnya sendi perekonomian negara, dan intoleransi dan krisis kepribadian bangsa.

Gerakan nasional revolusi mental melalui jalur pendidikan terkait erat dengan pengembangan soft skills dalam pendidikan dan pembelajaran. Namun demikian, perlu menjadi perhatikan bahwa gerakan nasional revolusi mental melalui jalur pendidikan ataupun pengembangan soft skills dalam pendidikan dan pembelajaran seharusnya tidak hanya dengan strategi internalisasi saja, akan tetetapi juga melalui pengamalan atau aktualisasi secara langsung. Aktualisasi dalam pengembangan nilai revolusi mental ataupun pengembangan soft skills dapat dilakukan dengan menerapkan suatu model pendidikan dan pembelajaran yang dapat mengajak siswa untuk menerapkan nilai revolusi mental ataup soft skills secara langsung dalam kegiatan pembelajaran.

Soft skills sendiri dapat dipahami melalui kutipan "soft skills refer to the cluster of personality traits, social graces, facility with language, personal habits, friendliness, and optimism that mark people to varying degrees. Soft skills complement hard skills, which are the technical requirements of a job (Schulz, 2008, p. 17). Kutipan tersebut menunjukkan bahwa soft skills merupakan bagian dari kepribadian, sopan santun, kemampuan berbahasa dan berkomunikasi, kebiasaan pribadi, keramahan, dan optimisme yang menandai orang untuk berbagai derajat. Soft skills melengkapi hard skill, yang merupakan persyaratan teknis dalam pekerjaan. Soft skills memang terkait erat dengan pembelajaran karakter atau pendidikan moral dan etika. Hal ini disebabkan soft skills merupakan bagian dari karakter dan keterampilan interpersonal yang menjadi ciri hubungan seseorang dengan orang lain. Kristjansson (2015, p. 5) menjelaskan bahwa pendidikan karakter dapat dilaksanakan melalui pendidikan soft skills atau pendidikan nonkognitif. Soft skills akan mempengaruhi seberapa baik seseorang berinteraksi dengan orang lain, dan biasanya menjadi bagian yang pasti dari karakter dan kepribadian seseorang.

Peluang mengajarkan soft skills bisa dijalankan oleh semua mata pelajaran. Namun demikian, fakta yang terjadi di dunia pendidikan menunjukkan bahwa tanggung jawab dunia pendidikan untuk membentuk kepribadian dan karakter siswa seringkali dijadikan sebagai beban untuk mata pelajaran tertentu, yaitu Pendidikan Kewarganegaraan atau PKn. Padahal, soft skills seharusnya diintegrasikan dalam seluruh mata pelajaran termasuk Pendidikan Jasmani, Olahraga, dan Kesehatan atau lebih dikenal dengan sebutan pelajaran 
olahraga. Pendidikan Jasmani, Olahraga, dan Kesehatan merupakan mata pelajaran wajib dalam kurikulum pendidikan dasar dan menengah sebagaimana tertuang dalam UndangUndang Nomor 20 Tahun 2003 tentang Sistem Pendidikan Nasional. Pasal 37 Ayat 1 Butir h Undang-Undang Nomor 20 Tahun 2003 tentang Sistem Pendidikan Nasional mengamanatkan bahwa "kurikulum pendidikan dasar dan menengah wajib memuat pendidikan jasmani dan olahraga. Pendidikan Jasmani, Olahraga, dan Kesehatan juga diatur dalam Undang-Undang Nomor 3 Tahun 2005 tentang Sistem Keolahragaan Nasional. Pasal 18 Ayat (1) Undang-Undang Nomor 3 Tahun 2005 tentang Sistem Keolahragaan Nasional menyebutkan bahwa "olahraga pendidikan diselenggarakan sebagai bagian proses pendidikan", dan Pasal 18 Ayat 4 Undang-Undang Nomor 3 Tahun 2005 tentang Sistem Keolahragaan Nasional yang menyebutkan bahwa "olahraga pendidikan pada jalur pendidikan formal dilaksanakan pada setiap jenjang pendidikan".

Pendidikan Jasmani, Olahraga, dan Kesehatan lebih identik dengan kepentingan fisik, kesegaran organik, dan kesegaran motorik. Pelajaran olahraga di sekolah yang saat ini dinamakan Pendidikan Jasmani, Olahraga, dan Kesehatan (PJOK) sebenarnya memiliki peranan yang sangat strategis sebagai alat pendidikan dan sebagai sarana menanamkan nilai-nilai sosial dan kepribadian yang positif yang bisa dibentuk melalui olahraga. Dewantara (1967) berpendapat bahwa selain unsur kesenangan dan kesehatan badan, olahraga juga bermanfaat untuk pendidikan batin guna mendidik tabiat: sejuk hati, seksama, awas, dan tertib sehingga dalam pelaksanaannya olahraga harus selalu dihubungkan dengan rasa kesopanan.

Terjadinya perubahan-perubahan paradigma pendidikan yang menempatkan manusia sebagai sumber daya yang utuh, memberikan arah kebijakan dalam meletakkan kerangka bagi pembangunan pendidikan di masa mendatang. Secara substansi, arah pendidikan harus dapat membekali peserta didik dengan kompetensi pada kemampuan memecahkan masalah, komunikasi, hubungan sosial dan interpersonal, kemandirian, etika, dan estetika. Terlepas dari berbagai ramuan mujarab yang ditawarkan, pengembangan soft skills di lembaga pendidikan formal memang harus dilakukan secara integratif dan menyeluruh. Sebagai upaya pencapaian ke arah itu, setiap mata pelajaran termasuk Pendidikan Jasmani, Olahraga, dan Kesehatan selayaknya juga ditujukan untuk mengembangkan kemampuan soft skills melalui pendekatan pembelajaran yang bisa mengasah pengembangan kepribadian.

Pengembangan model pembelajaran soft skills terpadu dalam pembelajaran Pendidikan Jasmani, Olahraga, dan Kesehatan pada Sekolah Menengah Pertama perlu dilaksanakan di Kota Yogyakarta yang dikenal sebagai kota pendidikan atau kota pelajar. Image ini melekat pada Kota Yogyakarta berkaitan dengan sejarah dan peran kota ini dalam dunia pendidikan di Indonesia. Berbagai jenjang pendidikan tersedia di kota ini. Setiap tahun, banyak pelajar dari seluruh daerah di Indonesia bahkan manca negara datang ke Yogyakarta untuk menempuh pendidikan. Oleh karena itu, tidak berlebihan bila Yogyakarta disebut sebagai miniatur Indonesia.

Yogyakarta pantas disebut sebagai miniatur Indonesia karena banyaknya suku bangsa yang berdiam di kota ini untuk menimba ilmu. Hal ini tentunya menyebabkan tingginya akulturasi budaya di Kota Yogyakarta sendiri. Akulturasi budaya ini tentunya tidak hanya membawa dampak positif saja, akan tetetapi juga dampak negatif. Di antara dampak negatif tersebut adalah dalam hal pembentukan kepribadian. Selain itu, akulturasi budaya juga dapat menumbuhkan sifat dan sikap individualisme, tidak adanya rasa kepedulian terhadap orang lain. Padahal, bangsa Indonesia sendiri terkenal dengan bangsa yang menjunjung tinggi prinsip gotong royong.

Dampak negatif yang mungkin timbul dari akulturasi budaya yang terjadi di Kota Yogyakarta menuntut adanya pendidikan yang komprehensif guna membina kepribadian seperti halnya pendidikan soft skills yang terpadu dalam seluruh mata pelajaran, termasuk Pendidikan Jasmani, Olahraga, dan Kesehatan. Yogyakarta dikenal sebagai kota yang ramah, gotong royong, sangat toleran dan jauh dari kata keras. Sikap dan karakter tersebut termasuk dalam area soft skills. Namun demikian, peningkatan jumlah pendatang yang terjadi selama beberapa tahun terakhir, kekerasan di Kota Yogyakarta juga mengalami penigkatan. Dengan proses modernisasi dan 
dialektika politik, karakter lokal semakin terdesak akibat ketidakseimbangan antara akselerasi budaya dan modernisasi.

Permasalahan yang terjadi di Kota Yogyakarta yang multikultur ini semakin mendesak agar pendidikan soft skills menjadi perhatian dan perlu dilaksanakan. Perbaikan pendidikan di Kota Yogyakarta akan membawa kemajuan dalam dunia pendidikan di seluruh Indonesia, mengingat tidak hanya warga Yogyakarta saja yang menuntut ilmu di kota ini, melainkan dari seluruh Indonesia. Pendidikan yang baik di Kota Yogyakarta guna menghasilkan sumber daya manusia yang memiliki hard skills maupun soft skills yang mumpuni akan membekali generasi muda yang berasal dari seluruh daerah di Indonesia agar dapat mengembangkan dan membangun daerahnya masing-masing di kemudian hari.

Pembelajaran di sekolah-sekolah di Yogyakarta masih kurang memperhatikan pengembangan bagi dimensi soft skills. Begitu pula halnya pada Pembelajaran Penjasorkes di Sekolah Menengah Pertama di Kota Yogyakarta. Berdasarkan hasil studi pendahuluan yang dilakukan peneliti melalui wawancara dengan guru dan siswa pada beberapa Sekolah Menengah Pertama di Kota Yogyakarta diketahui bahwa dalam pembelajaran Penjasorkes yang telah dilaksanakan oleh guru, pengembangan soft skills belum dilaksanakan secara optimal. Belum ada perhatian khusus dari guru untuk mengembangkan soft skills dalam pembelajaran Penjasorkes. Pada dasarnya, guru sudah memiliki pandangan bahwa dalam pembelajaran Penjasorkes keterampilan yang dipelajari bukan hanya keterampilan gerak dan fisik semata, melainkan terkait pula dengan keterampilan sosial, seperti berempati pada orang lain, menahan sabar, memberikan respek dan penghargaan pada orang lain, mempunyai motivasi yang tinggi, serta banyak lagi. Namun demikian, dalam pelaksanaan pembelajaran guru masih belum memberikan fokus perhatian pada pengembangan soft skills siswa.

Pengembangan pembelajaran soft skills terpadu dalam pembelajaran Penjasorkes Sekolah Menengah Pertama, perlu diperhatikan beberapa area soft skills yang harus ditanamkan. O'Brien (2010, p. 81) mengungkapkan bahwa soft skills dapat dikategorikan ke dalam 7 area yang disebut Winning
Characteristics, yaitu communication skills (kemampuan komunikasi), organizational skills (kemampuan organisasi), leadership (kepemimpinan), logic (logika), effort (upaya), group skills (kemampuan bekerja sama), dan ethics (etika). Keterampilan komunikasi sebagai bagian dari soft skills yang dimaksudkan meliputi keterampilan komunikasi lisan dan komunikasi tulisan. Keterampilan organisasi adalah keterampilan yang dimiliki seseorang dalam mengorganisasi, baik dirinya maupun orang-orang di sekitarnya. Keterampilan kepemimpinan ini bermakna bahwa seseorang memiliki jiwa kepemimpinan, dan dalam melakukan kepemimpinannya itu, ia termasuk sebagai pemimpin yang efektif. Keterampilan logika artinya keterampilan yang berbasiskan penalaran. Effort skills adalah keterampilan dalam melakukan upaya. Kemampuan bekerja sama adalah keterampilan yang harus dimiliki seseorang saat ia berada di tengah-tengah lingkungan dan manusia yang lain. Keterampilan etika adalah keterampilan untuk belajar membedakan mana yang salah dan mana yang benar, lalu memilih dan melakukan tindakan yang benar.

Ketujuh area soft skills sesungguhnya sangat sesuai untuk diintegrasikan dalam pendidikan soft skills pada pembelajaran Pendidikan Jasmani, Olahraga, dan Kesehatan. Pendidikan jasmani juga terkait dengan respons emosional, hubungan personal, perilaku kelompok, pembelajaran mental, intelektual, emosional, dan estetika. Pendidikan melalui fisikal maksudnya adalah pendidikan melalui aktifitas fisikal (aktivitas jasmani), tujuannya mencakup semua aspek perkembangan kependidikan, termasuk pertumbuhan mental, sosial siswa. Manakala tubuh sedang ditingkatkan secara fisik, pikiran (mental) harus dibelajarkan dan dikembangkan, dan selain itu perlu pula berdampak pada perkembangan sosial, seperti belajar bekerja sama dengan siswa lain.

Penelitian ini meliputi analisis secara teoretis untuk mendapatkan informasi tentang kesesuaian indikator serta analisis empiris untuk mengungkap kualitas pengembangan atribut soft skills. Oleh karena itu, perlu dilakukan suatu penelitian pengembaangan untuk menyusun suatu model pembelajaran soft skills terpadu dalam pembelajaran penjasorkes sekolah menengah pertama. Model pembelajaran soft skills yang dikembangkan 
merupakan pembelajaran soft skills terpadu. Pembelajaran terpadu merupakan suatu pendekatan dalam pembelajaran yang secara sengaja mengaitkan beberapa aspek baik dalam intramata pelajaran maupun antarmata pelajaran. Dalam model pembelajaran yang dikembangkan, aspek yang dikaitkan adalah materi pembelajaran Penjasorkes dengan materi pembelajaran soft skills. Suyanto \& Jihad (2013, p. 11) menjelaskan bahwa pembelajaran terpadu merupakan suatu pendekatan pembelajaran yang menghubungkan secara terintegrasi berbagai bidang yang mencerminkan dunia riil di sekeliling dan dalam rentang kemampuan dan perkembangan siswa.

Penelitian ini dilaksanakan melalui pendekatan penelitian pengembangan. Pengembangan yaitu penelitian yang digunakan untuk mengembangkan atau membuat produk baru melalui proses atau langkah-langkah yang dapat dipertanggung jawabkan. Dalam penelitian ini, produk yang dihasilkan berupa petunjuk pembelajaran soft skills pada mata pelajaran Pendidikan Jasmani, Olahraga, dan Kesehatan. Dengan merujuk pada latar belakang yang telah diuraikan sebelumnya, peneliti tertarik untuk melakukan penelitian dengan judul "Pengembangan Model Pembelajaran Soft skills Terpadu dalam Pembelajaran Penjasorkes Sekolah Menengah Pertama".

\section{METODE}

Penelitian ini menggunakan jenis penelitian dan pengembangan atau Research \& Development. Penelitian Research \& Development ini dilakukan dengan tujuan untuk menghasilkan produk berupa model pembelajaran soft skills terpadu dalam pembelajaran Penjasorkes Sekolah Menengah Pertama. Hasil dari model pembelajaran diharapkan menjadi dasar bagi praktisi pendidikan untuk mengambil kebijakan kedepan dalam rangka perbaikan pembelajaran soft skills terpadu dalam pembelajaran Penjasorkes di Sekolah Menengah Pertama.

Penetapan model pengembangan ini terdiri dari sepuluh urutan sebagai berikut (Gall, Gall, \& Borg, 2003, p. 775): (1) melakukan penelitian dan pengumpulan informasi; (2) melakukan perencanaan (pendefinisian, perumusan tujuan, penentuan urutan); (3) mengembangkan produk bentuk awal (penyiapan materi pembelajaran, penyusunan buku pe- gangan, dan perlengkapan evaluasi); (4) melakukan uji coba lapangan pendahuluan; (5) melakukan revisi terhadap produk utama (sesuai dengan saran-saran dan hasil uji coba pendahuluan); (6) melakukan uji coba lapangan utama; (7) melakukan revisi terhadap produk utama (revisi produk berdasarkan saransaran dari hasil uji coba lapangan utama); (8) melakukan uji coba lapangan operasional; (9) melakukan revisi terhadap produk akhir (revisi produk seperti yang disarankan oleh hasil uji coba lapangan operasional); (10) mendesiminasikan dan mengimplementasikan produk (membuat laporan).

Langkah-langkah yang dilakukan pada penelitian ini mengacu pada urutan yang dikemukan oleh Gall, Gall, dan Borg yang telah diuraikan.

Subjek uji coba pada penelitian ini diambil dari kelas VII SMP Negeri di Kota Yogyakarta, yang meliputi guru, siswa, dan kepala sekolah selaku pimpinan. Subjek uji coba penelitian ini diambil 4 dari 16 SMP Negeri di Kota Yogyakarta. SMP Negeri di Kota Yogyakarta tersebar di berbagai lokasi di tengah Kota Yogyakarta. Pemilihan kelas VII dari SMP Negeri sebagai subjek uji coba disebabkan SMP Negeri dapat dijadikan tolok ukur dalam proses pendidikan. Di samping itu, guru Penjasorkes pada SMP Negeri mayoritas adalah pegawai negeri sipil (PNS) yang memiliki pendidikan paling tidak strata 1 (S1) dalam bidang ilmu Pendidikan Jasmani, Olahraga, dan Kesehatan.

Data yang diperoleh dalam penelitian ini merupakan data kuantitatif serta data kualitatif. Data tersebut memberi gambaran tentang tahap perancangan model, efektifitas model pembelajaran, proses pembelajaran yang telah dilaksanakan, dan hasil yang dicapai dari proses pembelajaran soft skills yang telah dilaksanakan.

Pengumpulan data dilakukan melalui wawancara, penyebaran angket, dan observasi. Wawancara dilakukan pada saat studi pendahuluan yang dilakukan tidak terstruktur. Instrumen yang digunakan dalam penelitian ini adalah angket dan pedoman observasi berupa check list.

Analisis data deskriptif kualitatif dilakukan untuk memberikan narasi yang logis sesuai dengan tujuan penelitian. Analisis kuantitatif yang dilakukan dalam penelitian ini meliputi analisis kevalidan, keterlaksana- 
an, keefektifan, dan kepraktisan model pembelajaran yang dikembangkan. Analisis data kevalidan model dilakukan dengan analisis deskriptif dan pengukuran tingkat reliabilitas antarpenilai (interrater reliability) melalui Coefficient Cohen's Kappa. Analisis data keterlaksanaan model dilakukan melalui analisis deskriptif dan perhitungan tingkat percentages of agreements antarpenilai. Analisis data keefektifan, kepraktisan, dan dampak penerapan model pembelajaran soft skills terpadu dalam pembelajaran Penjasorkes di Sekolah Menengah Pertama terhadap siswa dilakukan melalui uji beda dengan metode paired sample t test.

\section{HASIL DAN PEMBAHASAN}

\section{Pengembangan Produk Awal}

Pengembangan Pengembangan model pembelajaran Soft Skill Terpadu dalam pembelajaran Penjasorkes dilakukan melalui penelitian Research \& Development. Pengembangan model pembelajaran Soft Skill Terpadu dalam pembelajaran Penjasorkes yang dapat meningkatkan soft skills siswa pada Sekolah Menengah Pertama diuraikan sebagai berikut.

Pertama, tahapan pengembangan model dilakukan dalam 3 tahap utama, yaitu tahap studi pendahuluan, tahap pengembangan, dan tahap evaluasi. Studi pendahuluan dilakukan melalui pencarian informasi dengan melalui wawancara dan observasi awal kegiatan pembelajaran Penjasorkes di Sekolah Menengah Pertama, serta penyusunan rencana penelitian. Tahap kedua adalah studi pengembangan yang dilakukan melalui penyusunan model awal, uji coba lapangan pendahuluan dengan metode FGD bersama praktisi pendidikan, uji coba lapangan, dan revisi hasil uji coba sehingga menghasilkan model hipotetik. Selanjutnya, dilakukan tahap ketiga, yaitu tahap evaluasi melalui implementasi model pembelajaran dan revisi akhir guna memperoleh model yang layak secara teoritis dan secara empiris.

Kedua, hasil studi pendahuluan memberikan masukan kepada peneliti untuk menyusun perangkat model pembelajaran Soft Skill Terpadu dalam pembelajaran Penjasorkes di Sekolah Menengah Pertama. Adapun produk yang dikembangkan sesuai dengan kebutuhan pendidikan adalah buku panduan model pembelajaran beserta perangkat instrumen penilaian. Instrumen penilaian model pembelajaran yang dikembangkan terdiri dari instrumen: (1) penilaian validasi model pembelajaran, (2) lembar penilaian keterlaksanaan model pembelajaran, (3) penilaian penilaian keefektifan model pembelajaran, (4) penilaian penilaian kepraktisan model pembelajaran, dan (5) lembar penilaian hasil belajar. Selain itu, terdapat beberapa instrumen lainnya untuk menilai keterlaksanaan model pembelajaran soft skill terpadu yang terdiri dari: (1) instrumen penilaian sikap guru, (2) instrumen penilaian kinerja guru, (3) instrumen penilaian perilaku siswa, (4) instrumen penilaian respons siswa, dan (5) instrumen penilaian proses pembelajaran.

Ketiga, Soft skills yang dikembangkan pada pembelajaran Soft Skill Terpadu dalam pembelajaran Penjasorkes di Sekolah Menengah Pertama adalah; (1) communication skills (kemampuan komunikasi), (2) organizational skills (kemampuan organisasi), (3) leadership (kepemimpinan), (4) logic (logika), (5) effort (upaya), (6) group skills (kemampuan bekerja sama), dan (7) ethics (etika). Jenis soft skills ini dikembangkan berdasarkan hasil diskusi pada studi pendahuluan. Para praktisi pendidikan sepakat bahwa soft skills yang dapat dikembangkan secara terpadu pada mata pelajaran Penjasorkes meliputi ketujuh soft skills tersebut.

\section{Hasil Uji coba Produk}

\section{Tahap Uji Coba}

Keterlaksanaan model pembelajaran Soft skills terpadu dalam pembelajaran Penjasorkes di Sekolah Menengah Pertama dapat dilihat dari pelaksanaan uji coba produk. Setelah semua perangkat buku panduan dan model pembelajaran dan instrumen model pembelajaran Soft skills terpadu dalam pembelajaran Penjasorkes di Sekolah Menengah Pertama dikembangkan dan memenuhi standar validitas, maka model pembelajaran dilaksanakan untuk mengetahui keterlaksanaan model pembelajaran Soft skills terpadu dalam pembelajaran Penjasorkes di Sekolah Menengah Pertama.

Keterlaksanaan model pembelajaran Soft skills terpadu dalam pembelajaran Penjasorkes di Sekolah Menengah Pertama dapat 
dikatakan baik. Sikap guru Penjasorkes dalam mengajar tergolong dalam kategori sangat baik. Guru Penjasorkes memiliki pilihan dan kendali diri yang sangat baik, serta mampu menjadi fasilitator dalam pembelajaran dengan sangat baik. Perhatian guru Penjasorkes terhadap siswa tergolong baik. Begitu pula halnya dengan kemampuan guru mengevaluasi diri dan kemampuan untuk berkomunikasi dan mengorganisasi siswa.

Dari segi kinerja dapat dilihat bahwa guru Penjasorkes memiliki kinerja yang sangat baik. Respons siswa terhadap model pembelajaran Soft skills terpadu dalam pembelajaran Penjasorkes di Sekolah Menengah Pertama yang telah diterapkan juga tergolong sangat baik. Perilaku siswa selama pembelajaran berlangsung tergolong sangat baik. Secara keseluruhan, proses pembelajaran berjalan dengan baik. Kondisi ini memperlihatkan bahwa keterlaksanaan model pembelajaran Soft skills terpadu dalam pembelajaran Penjasorkes di Sekolah Menengah Pertama pada dasarnya sudah tergolong sangat baik.

Keterlaksanaan produk adalah terlaksananya seluruh aktifitas pembelajaran sesuai dengan sintaks atau tahapan-tahapan pembelajaran yang telah dirancang pada buku pedoman pembelajaran. Persentasi keterlaksanaan produk diamati oleh pengamat yang membantu peneliti mengamati seluruh aktifitas selama proses pembelajaran berlangsung. Tingkat keterlaksanaan model pembelajaran Soft skills terpadu diukur melalui pengamatan oleh 3 orang pengamat terhadap seorang guru yang sedang menerapkan produk selama pembelajaran berlangsung. Pengamatan dilakukan sebanyak 1 kali dalam 1 periode pelaksanaan pembelajaran (6 minggu). Pada instrumen pengamatan terhadap tingkat keterlaksanaan ini terdapat 15 item pernyataan yang harus dijawab dengan "Ya" untuk item yang terlaksana dan dengan "Tidak" jika tidak terlaksana. Hasil pengamatan dan penilaian terhadap tingkat keterlaksanaan produk Soft skills terpadu disajikan pada Tabel 1.

Pada Tabel 1 dan Gambar 1 tampak bahwa tidak ada perbedaan yang signifikan hasil pengamatan antara pengamat terhadap tingkat keterlaksanaan model pembelajaran Soft skills terpadu pada uji coba. Masingmasing pengamat menunjukkan persentase sebesar $86,7 \%$ untuk pengamat 1 dan 93,3\% untuk pengamat 2 dan pengamat 3 . Untuk menjamin reliabilitas hasil pengamatan keterlaksanaan model pembelajaran Soft skills terpadu dalam pembelajaran Penjasorkes di Sekolah Menengah Pertama, dilakukan analisis reliabilitas antarpengamat dengan menggunakan formula Persentase Kesepakatan. Hasil analisis Persentase Kesepakatan antar sesama pengamat dapat dilihat pada Tabel 2.

Tabel 1. Analisis Data Keterlaksanaan Produk pada Uji Coba

\begin{tabular}{ccc}
\hline \multirow{2}{*}{ Pengamat } & \multicolumn{2}{c}{ Rata-rata Keterlaksanaan } \\
\cline { 2 - 3 } & \multicolumn{2}{c}{ Produk } \\
\cline { 2 - 3 } 1 & Persentase & Kategori \\
\hline 2 & $86,7 \%$ & Baik \\
3 & $93,3 \%$ & Baik \\
\hline
\end{tabular}

Keterangan Penilaian:

$>50 \%$ : baik

$\leq 50 \%$ : tidak baik

Persentase keterlaksanaan tersebut dapat juga dilihat pada Gambar 1.

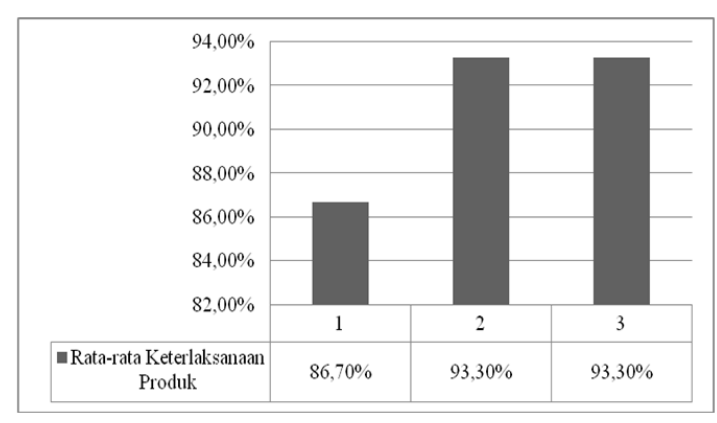

Gambar 1. Diagram Batang Hasil Analisis Data Keterlaksanaan Uji Coba

Tabel 2. Analisis Persentase Kesepakatan Keterlaksanaan Model Pembelajaran pada Uji Coba

\begin{tabular}{ccc}
\hline \multicolumn{3}{c}{ Hasil Pengamatan Keterlaksanaan } \\
\hline Sepakat & $\begin{array}{c}\text { Tidak } \\
\text { sepakat }\end{array}$ & $\begin{array}{c}\text { Persentase } \\
\text { Kesepakatan }\end{array}$ \\
\hline 12 & 3 & $80 \%$ \\
\hline
\end{tabular}

Hasil pengamatan dari 3 orang pengamat yang merupakan teman sejawat guru Penjasorkes menunjukkan nilai persentase kesepakatan sebesar $80 \%$ yang termasuk dalam kategori baik (good agreement). Hasil analisis tersebut menunjukkan bahwa ketiga pengamat memiliki persepsi pemahaman yang hampir sama bahwa keterlaksanaan sintaks model pembelajaran Soft skills terpadu dalam 
pembelajaran Penjasorkes di Sekolah Menengah Pertama tergolong baik sesuai yang diharapkan diharapkan dengan tingkat keajegan yang tinggi.

Keefektifan model pembelajaran diukur melalui lembar penilaian tersendiri. Lembar keefektifan dinilai oleh guru Penjasorkes yang menggunakan model pembelajaran. Hasil penilaian dari beberapa aspek yang dinilai dalam lembar keefektifan model pembelajaran dapat dilihat pada Gambar 2.

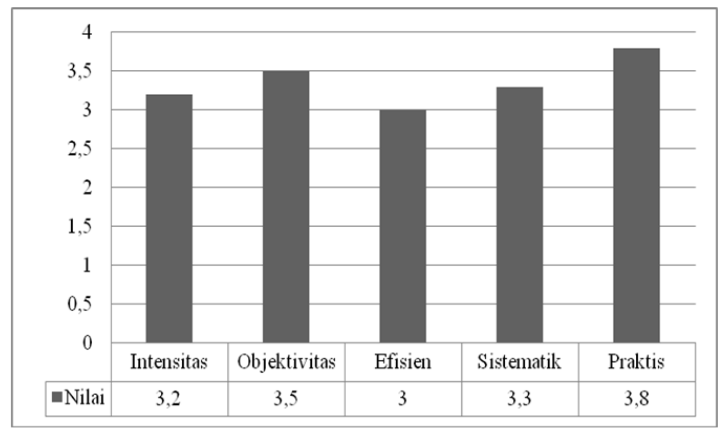

Gambar 2. Diagram Batang Hasil Analisis Data Keefektifan

Gambar 2 memperlihatkan bahwa model pembelajaran soft skills terpadu dalam pembelajaran Penjasorkes di Sekolah Menengah Pertama dinilai sangat efektif oleh guru. Rata-rata hasil penilaian keefektifan produk menunjukkan nilai sebesar 3,4 yang berada dalam kategori sangat efektif. Seluruh aspek keefektifan memiliki nilai yang tergolong sangat efektif, kecuali pada aspek efisien. Aspek yang memiliki tingkat keefektifan paling tinggi adalah kepraktisan produk, yaitu sebesar 3,8. Artinya model pembelajaran soft skills terpadu dalam pembelajaran Penjasorkes di Sekolah Menengah Pertama sangat efektif digunakan untuk mengembangkan karakter siswa.

Berdasarkan gambar di atas terlihat hasil penilaian guru pada uji coba menunjukkan bahwa penerapan model pembelajaran Soft skills terpadu dalam pembelajaran Penjasorkes di Sekolah Menengah Pertama sangat praktis. Selain itu, model pembelajaran juga memiliki objektivitas yang baik. Proses pembelajaran yang berjalan selama 6 minggu juga telah menunjukkan bahwa pembelajaran berlangsung dengan baik.

Setelah diketahui bahwa model pembelajaran soft skills terpadu dalam pembelajaran Penjasorkes di Sekolah Menengah
Pertama efektif untuk diterapkan, perlu dinilai kepratisan model pembelajaran. Kepraktisan model pembelajaran soft skills terpadu dalam pembelajaran Penjasorkes di Sekolah Menengah Pertama dinilai oleh guru sebagai pengguna model pembelajaran. Hasil penilaian guru terhadap kepraktisan model pembelajaran soft skills terpadu dalam pembelajaran Penjasorkes di Sekolah Menengah Pertama setelah pelaksanaan selama 6 minggu menunjukkan bahwa model pembelajaran soft skills terpadu dalam pembelajaran Penjasorkes di Sekolah Menengah Pertama termasuk dalam kategori praktis. Secara keseluruhan dapat diketahui bahwa rata-rata penilaian terhadap keseluruhan aspek bernilai sebesar 3,15 dengan kategori sangat praktis. Apabila dilihat dari masing-masing aspek maka dapat diketahui bahwa aspek yang paling praktis adalah sistem sosial produk dengan nilai rata-rata sebesar 3,3 dengan kategori sangat praktis.

Produk belum dapat dikatakan efektif dengan baik tanpa diiringi oleh keberhasilan output pembelajaran. Oleh karena itu, perlu dilihat hasil pembelajaran soft skills terpadu yang dinilai oleh guru.

Soft skills siswa sebelum dan sesudah pelaksanaan pembelajaran soft skills terpadu dalam pembelajaran Penjasorkes di Sekolah Menengah Pertama mengalami peningkatan. Jenis soft skills yang berkembang dengan sangat baik adalah logika, upaya, dan etika. Secara kuantitatif, soft skills tertinggi adalah nilai logika, upaya, dan etika, yaitu sebesar 3,2. Kemampuan berkomunikasi, kemampuan organisasi, dan kepemimpinan menunjukkan nilai yang sama, yaitu 3,00. Kemampuan kerja sama memiliki nilai sebesar 3,1. Apabila dilihat dari fakta yang terjadi di lapangan, dapat dipahami bahwa ada perubahan pada pengembangan soft skills pada mayoritas siswa. Hal ini dapat dilihat dari hasil pegukuran skala soft skills yang diberikan pada siswa.

Selanjutnya, dapat diketahui hasil uji paired t test guna mengetahui perbedaan pengembangan soft skills dalam diri siswa sebelum dan sesudah pelaksanaan pembelajaran Penjasorkes. Hasil uji t dapat dilihat pada Tabel 3.

Dari Tabel 3 terlihat bahwa pada pengujian antara hasil soft skills awal dan soft skills akhir yang berkembang dalam diri sis$\mathrm{wa}$, nilai $\mathrm{t}_{\text {hitung }}$ adalah sebesar 5,406 dengan nilai signifikansi 0,000 . Nilai $\mathrm{t}_{\text {tabel }}$ untuk $\alpha=5 \%$ 
adalah sebesar 2,039. Hasil pengujian ini menunjukkan bahwa nilai $\mathrm{t}_{\text {hitung }}>\mathrm{t}_{\text {tabel }}$, yaitu $5,406>2,039$ dan nilai signifikansi $<0,05$. Kondisi ini menunjukkan bahwa ada perbedaan yang signifikan antara soft skills awal dengan soft skills akhir. Hasil ini menunjukkan bahwa ada pengaruh model pembelajaran soft skills terpadu dalam pembelajaran Penjasorkes di Sekolah Menengah Pertama terhadap pengembangan soft skills dalam diri siswa. Dengan demikian dapat dikatakan bahwa model pembelajaran soft skills terpadu dalam pembelajaran Penjasorkes di Sekolah Menengah Pertama efektif untuk mengembangkan soft skills siswa.

Tabel 3. Hasil Uji Paired Sample t Test Data Uji Coba

\begin{tabular}{lcccc}
\hline Statistik & $\mathrm{t}_{\text {hitung }}$ & $\mathrm{df}$ & $\mathrm{t}_{\text {tabel }}$ & Sig. \\
\hline Soft Skills Awal- Soft & 5,40 & 3 & 2,03 & 0,00 \\
Skills Akhir & 6 & 1 & 9 & 0 \\
\hline
\end{tabular}

Tahap Implementasi

Seperti halnya pada uji coba produk sebelumnya, telah dikemukakan bahwa model pembelajaran soft skills terpadu dalam pembelajaran Penjasorkes di Sekolah Menengah Pertama dikatakan efektif apabila guru dapat meningkatkan kualitas proses pembelajaran di kelas serta adanya respons positif dari siswa. Keterlaksanaan model pembelajaran soft skills terpadu dalam pembelajaran Penjasorkes yang diimplementasikan di Sekolah Menengah Pertama dapat dikatakan sangat baik. Ketiga Sekolah Menengah Pertama yang dijadikan sebagai lokasi penelitian memiliki rata-rata nilai untuk sikap guru Penjasorkes yang tergolong dalam kategori sangat baik pada seluruh aspek. Guru Penjasorkes memiliki pilihan dan kendali diri yang sangat sangat baik, serta mampu berkomunikasi dan memimpin siswa dengan baik. Perhatian guru Penjasorkes terhadap siswa tergolong sangat baik. Begitu pula halnya dengan kemampuan guru dalam mengorganisasi siswa.

Kinerja guru Penjasorkes juga sudah tergolong dalam kategori sangat baik. Perilaku siswa sudah tergolong baik bahkan sangat baik dan respons siswa terhadap pembelajaran yang dilaksanakan juga tergolong sangat baik. Proses pembelajaran soft skills terpadu dalam pembelajaran Penjasorkes yang dimplementasikan di Sekolah Menengah Pertama sudah berjalan dengan sangat baik. Hal ini memperlihatkan bahwa keterlaksanaan model pembelajaran soft skills terpadu dalam pembelajaran Penjasorkes di Sekolah Menengah Pertama sudah tergolong sangat baik.

Sebagaimana telah dijelaskan pada uji coba sebelumnya bahwa analisis kepraktisan model pembelajaran soft skills terpadu dalam pembelajaran Penjasorkes di Sekolah Menengah Pertama adalah tingkat keterlaksanaan seluruh tahapan pembelajaran (sintaks). Kegiatan pengamatan pada saat implementasi dilakukan sebanyak 1 kali. Analisis data dapat dilihat pada Lampiran 8, 9, dan 10. Hasil analisis keterlaksanaan model pembelajaran soft skills terpadu dalam pembelajaran Penjasorkes di Sekolah Menengah Pertama dapat dilihat pada Tabel 4.

Tabel 4. Analisis Data Keterlaksanaan Produk pada Implementasi

\begin{tabular}{|c|c|c|c|c|c|}
\hline \multirow{2}{*}{$\begin{array}{l}\text { Peng- } \\
\text { amat }\end{array}$} & \multicolumn{5}{|c|}{ Rata-rata Keterlaksanaan Produk } \\
\hline & \multicolumn{2}{|c|}{ SMP 2} & \multicolumn{2}{|c|}{ SMP 3} & SMP 7 \\
\hline 1 & $100 \%$ & Baik & $80 \%$ & Baik & $93,3 \%$ Baik \\
\hline 2 & $93,3 \%$ & Baik & $93,3 \%$ & Baik & $86,7 \%$ Baik \\
\hline 3 & $100 \%$ & Baik & $86,7 \%$ & Baik & 93,3\% Baik \\
\hline $\begin{array}{l}\text { Keter } \\
>50^{\circ} \\
\leq 50^{\circ}\end{array}$ & $\begin{array}{l}\text { angan } \mathrm{F} \\
\frac{1}{0} \text { : ba } \\
0 \quad \text { : tid }\end{array}$ & nilaia & & & \\
\hline
\end{tabular}

Persentase keterlaksanaan tersebut dapat juga dilihat pada Gambar 3.

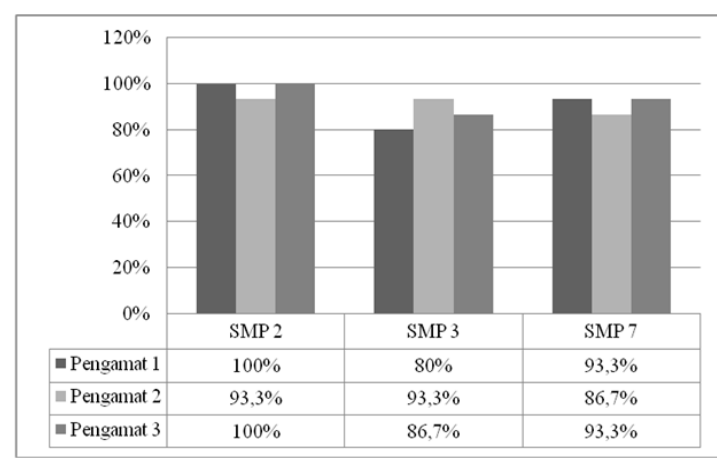

Gambar 3. Diagram Batang Hasil Analisis Data Keefektifan

Pada Tabel 4 dan Gambar 3 tampak bahwa ada perbedaan hasil pengamatan antara pengamat di ketiga sekolah terhadap tingkat keterlaksanaan model pembelajaran Soft skills terpadu pada saat implementasi. Pada SMP 2, pengamat 1 menilai persentase keterlaksanaan sebesar $100 \%$, pengamat 2 menilai persentase keterlaksanaan sebesar 93,3\%, sedangkan pe- 
ngamat 3 sebesar $100 \%$. Pada SMP 3, pengamat 1 menilai persentase keterlaksanaan sebesar $80 \%$, pengamat 2 menilai persentase keterlaksanaan sebesar 93,3\%, sedangkan pengamat 3 sebesar 86,7\%. Pada SMP 3, pengamat 1 menilai persentase keterlaksanaan sebesar $93,3 \%$, pengamat 2 menilai persentase keterlaksanaan sebesar $86,7 \%$, sedangkan pengamat 3 sebesar 93,3\%. Untuk membuktikan reliabilitas hasil pengamatan keterlaksanaan model pembelajaran Soft skills terpadu dalam pembelajaran Penjasorkes di Sekolah Menengah Pertama, dilakukan analisis reliabilitas antarpengamat dengan menggunakan formula Persentase Kesepakatan. Hasil analisis Persentase Kesepakatan antar sesama pengamat dapat dilihat pada Tabel 5 berikut.

Tabel 5. Analisis Persentase Kesepakatan Keterlaksanaan Model Pembelajaran pada Tahap Implementasi

\begin{tabular}{lcccc}
\hline No Sekolah & \multicolumn{3}{c}{ Hasil Pengamatan Keterlaksanaan } \\
\cline { 2 - 4 } & & Sepakat & $\begin{array}{c}\text { Tidak } \\
\text { Sepakat }\end{array}$ & $\begin{array}{c}\text { Persentase } \\
\text { Kesepakatan }\end{array}$ \\
\hline 1. & SMP 2 & 14 & 1 & $93,3 \%$ \\
2. & SMP 3 & 11 & 4 & $73,3 \%$ \\
3. & SMP 7 & 12 & 3 & $80 \%$ \\
\hline
\end{tabular}

Hasil pengamatan dari 3 orang pengamat menunjukkan nilai PA sebesar 93,3\% pada SMP 2, 73,3\% pada SMP 3, dan sebesar $80 \%$ pada SMP 7. Kedua nilai ini termasuk dalam kategori baik (good agreement). Hasil analisis tersebut menunjukkan bahwa kedua pengamat memiliki persepsi pemahaman yang hampir sama, bahwa keterlaksanaan sintaks model pembelajaran Soft skills terpadu dalam pembelajaran Penjasorkes di Sekolah Menengah Pertama tergolong baik sesuai yang diharapkan dengan tingkat keajegan yang tinggi.

Dalam implementasi model pembelajaran, keefektifan produk juga dinilai oleh guru yang menggunakan model pembelajaran. Penilaian guru terhadap keefektifan model pembelajaran soft skills terpadu dalam pembelajaran Penjasorkes di Sekolah Menengah Pertama menunjukkan bahwa keefektifan model pembelajaran juga diukur melalui lembar penilaian tersendiri. Hasil penilaian dari beberapa aspek yang dinilai dalam lembar keefektifan model pembelajaran dapat dilihat pada Gambar 4.

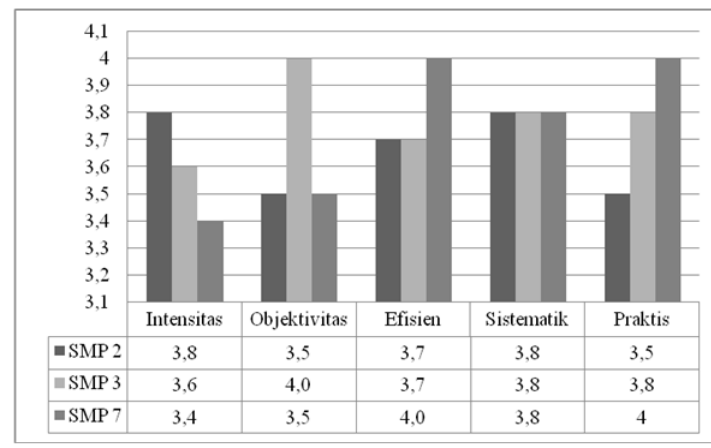

Gambar 4. Diagram Batang Hasil Analisis Data Keefektifan setelah Implementasi

Berdasarkan Gambar 4 di atas terlihat hasil penilaian guru pada implementasi menunjukkan bahwa penerapan model pembelajaran Soft skills terpadu dalam pembelajaran Penjasorkes di Sekolah Menengah Pertama sudah memenuhi kategori yang paling tinggi dalam hal intensitas, objektivitas, efisien, sistematik, dan praktis. Aspek yang memiliki nilai tertinggi dalam implementasi adalah efisien, sistematik, dan praktis. Aspek yang memiliki nilai terendah adalah intensitas. Namun demikian, seluruh aspek tersebut sudah memiliki nilai yang tergolong dalam kategori sangat efektif.

Model pembelajaran Soft skills terpa$d u$ dalam pembelajaran Penjasorkes di Sekolah Menengah Pertama dinilai sangat efektif oleh guru di ketiga Sekolah Menengah Pertama. Rata-rata hasil penilaian keefektifan produk menunjukkan nilai sebesar 3,7 yang berada dalam kategori sangat efektif. Seluruh aspek keefektifan memiliki nilai rata-rata yang tergolong sangat efektif. Aspek yang memiliki tingkat keefektifan paling tinggi adalah efisien, sistematik, dan praktis, yaitu sebesar 3,8 . Proses pembelajaran yang berjalan selama 6 minggu juga telah menunjukkan bahwa pembelajaran berlangsung dengan sangat baik.

Setelah diketahui bahwa implementasi model pembelajaran Soft skills terpadu dalam pembelajaran Penjasorkes di Sekolah Menengah Pertama berlangsung dengan sangat efektif, maka perlu dinilai kepraktisan model pembelajaran. Kepraktisan model pembelajaran Soft skills terpadu dalam pembelajaran Penjasorkes di Sekolah Menengah Pertama juga dinilai oleh guru pada ketiga Sekolah Menengah Pertama yang menjadi pengguna model pembelajaran. Hasil penilai- 
an guru terhadap kepraktisan model pembelajaran Soft skills terpadu dalam pembelajaran Penjasorkes di Sekolah Menengah Perta-ma setelah implementasi selama 6 minggu menunjukkan bahwa model pembelajaran Soft skills terpadu dalam pembelajaran Penjasorkes di Sekolah Menengah Pertama termasuk dalam kategori sangat praktis. Secara keseluruhan dapat diketahui bahwa rata-rata penilaian terhadap keseluruhan aspek bernilai sebesar 3,6 dengan kategori sangat praktis. Apabila dilihat dari masing-masing aspek maka dapat diketahui bahwa aspek yang paling praktis adalah sintaks dan prinsip reaksi produk dengan nilai rata-rata sebesar 3,8 dengan kategori sangat praktis.

Penilaian model pembelajaran Soft skills terpadu dalam pembelajaran Penjasorkes di Sekolah Menengah Pertama kembali dilakukan pada setelah implementasi model pembelajaran Soft skills terpadu dalam pembelajaran Penjasorkes di Sekolah Menengah Pertama. Berdasarkan hasil analisis penilaian produk dan penilaian instrumen setelah uji coba yang disajikan pada tabel di atas dapat diketahui bahwa hasil penilaian mayoritas berada dalam kategori sangat valid dan dapat digunakan. Selanjutnya, dilihat tingkat kesepakatan (reliabilitas) antar penilai tersebut dapat dijelaskan dengan menghitung koefisien reliabilitas antarpenilai menggunakan koefisien Cohen's Kappa (к). Model pembelajaran Soft skills terpadu dalam pembelajaran Penjasorkes dan perangkat penilaiannya yang dikembangkan memiliki kategori kevalidan yang tergolong sangat baik dan reliabel setelah implementasi.

Pada tahap implementasi, respons siswa juga dilakukan penilaian terhadap pegembangan soft skills siswa. Hasil penilaian terhadap pengembangan soft skills siswa pada tahap implementasi menunjukkan bahwa terjadi peningkatan soft skills dalam diri siswa pada SMP 2, SMP 3, dan SMP 7. Soft skills mengalami peningkatan setelah implemetasi model pembelajaran. Pada SMP 2 terdapat 3 soft skills yang berkembang dengan sangat baik, yaitu kepemimpinan, upaya, dan etika. Pada SMP 3, mayoritas soft skills berkembang dengan baik, yaitu kemampuan organisasi, upaya, kerja sama, dan etika. Sedikit berbeda, pada SMP 7 sudah memiliki 4 soft skills yang berkembang dengan sangat baik, yaitu kemampuan berkomunikasi, logika, upaya, dan kemampuan kerja sama. Hasil uji t dapat dilihat pada Tabel 6 .

Tabel 6. Hasil Uji Paired Sample t Test Data Implementasi

\begin{tabular}{crllll}
\hline No. Sekolah & Statistik & $\mathrm{t}_{\text {hitung }}$ & $\mathrm{t}_{\text {tabel }}$ & Sig. \\
\hline 1. SMP 2 & $\begin{array}{l}\text { Soft Skills } \\
\text { Awal- Soft } \\
\text { Skills Akhir }\end{array}$ & 12,591 & 2,039 & 0,000 \\
2. SMP 3 & $\begin{array}{l}\text { Soft Skills } \\
\text { Akhir - Soft }\end{array}$ & 7,927 & 2,032 & 0,000 \\
& Skills Akhir & & & \\
3. SMP 7 & $\begin{array}{l}\text { Soft Skills } \\
\text { Awal- Soft } \\
\text { Skills Akhir }\end{array}$ & 18,456 & 2,032 & 0,000 \\
& & & & \\
\hline
\end{tabular}

Dari Tabel 6 terlihat bahwa pada pengujian implementasi mpdel pembelajaran. Di SMP 2, perbandingan soft skills awal dan soft skills akhir yang berkembang pada siswa menunjukkan nilai $t_{\text {hitung }}$ sebesar 12,591 dengan nilai signifikansi 0,000 . Nilai $t_{\text {tabel }}$ untuk $\alpha=5 \%$ adalah sebesar 2,039 . Hasil pengujian ini menunjukkan bahwa nilai $t_{\text {hitung }}>t_{\text {tabel }}$, yaitu 12,591 > 2,039 dan nilai signifikansi < 0,05. Di SMP 3, perbandingan soft skills awal dan soft skills akhir yang berkembang pada siswa menunjukkan nilai $t_{\text {hitung }}$ sebesar 7,927 dengan nilai signifikansi 0,000 . Nilai $t_{\text {tabel }}$ untuk $\alpha=5 \%$ adalah sebesar 2,032. Hasil pengujian ini menunjukkan bahwa nilai $t_{\text {hitung }}>$ $\mathrm{t}_{\text {tabel}}$, yaitu 7,927> 2,032 dan nilai signifikansi $<0,05$.

Di SMP 7, perbandingan soft skills awal dan soft skills akhir yang berkembang pada siswa menunjukkan nilai $t_{\text {hitung }}$ sebesar 18,456 dengan nilai signifikansi 0,000 . Nilai $t_{\text {tabel }}$ untuk $\alpha=5 \%$ adalah sebesar 2,032. Hasil pengujian ini menunjukkan bahwa nilai $t_{\text {hitung }}$ $>t_{\text {tabel }}$, yaitu $18,456>2,032$ dan nilai signifikansi $<0,05$. Kondisi ini menunjukkan bahwa ada perbedaan yang signifikan antara soft skills awal dengan soft skills akhir. Begitu pula halnya dengan sekolah lainnya. Kondisi ini semakin menunjukkan bahwa ada perbedaan yang signifikan antara soft skills awal pembelajaran dengan soft skills akhir pembelajaran. Hasil ini menunjukkan bahwa ada pengaruh model pembelajaran soft skills terpadu dalam pembelajaran Penjasorkes di Sekolah Menengah Pertama terhadap pengembangan soft skills peserta didik. 


\section{Revisi Produk}

Setelah melalui Setelah melalui berbagai tahap dalam proses pengembangan, mulai dari FGD, penilaian kelompok kecil, dan penilaian akhir diperoleh draf produk akhir model pembelajaran soft skills terpadu dalam pembelajaran Penjasorkes di Sekolah Menengah Pertama. Data yang diperoleh dari hasil, FGD, uji coba, dan implementasi menjadi dasar untuk melakukan revisi model pembelajaran soft skills terpadu dalam pembelajaran Penjasorkes di Sekolah Menengah Pertama yang dikembangkan beserta instrumen penilaiannya secara keseluruhan. Produk ini telah terbukti valid, efektif, dan praktis, baik dari segi isi, bahasa, serta tampilan yang merupakan satu kesatuan. Berdasarkan penilaian praktisi pendidikan, terdapat beberapa faktor yang menjadi kekuatan model pembelajaran soft skills terpadu dalam pembelajaran Penjasorkes di Sekolah Menengah Pertama.

Temuan-temuan dari pelaksanaan uji coba dan respons yang diberikan praktisi pendidikan, digunakan untuk melakukan revisi model pembelajaran soft skills terpadu dalam pembelajaran Penjasorkes di Sekolah Menengah Pertama. Setelah uji coba, model pembelajaran soft skills terpadu dalam pembelajaran Penjasorkes di Sekolah Menengah Pertama beserta perangkat instrumen penilaiannya yang telah direvisi diujikan kembali pada implementasi dengan melibatkan siswa dan Sekolah Menengah Pertama yang lebih banyak. Secara umum, masukan yang menjadi saran perbaikan dalam penerapan model pembelajaran soft skills terpadu dalam pembelajaran Penjasorkes di Sekolah Menengah Pertama telah digunakan peneliti dalam melakukan revisi produk. Catatan-catatan revisi tersebut merupakan catatan revisi terhadap produk selama proses pengembangan, dari validasi produk sampai dengan tahap imple-mentasi.

Dalam pengembangan produk, telah dilakukan revisi sesuai dengan saran-saran revisi dari para praktisi pendidikan. Setelah melakukan revisi sesuai dengan masukan dan saran dari ahli dan praktisi pendidikan, produk telah divalidasi kembali pada akhir pelaksanaan implementasi model pembelajaran soft skills terpadu dalam pembelajaran Penjasorkes di Sekolah Menengah Pertama. Validasi akhir dilakukan dengan 8 orang praktisi pendidikan. Hasil implementasi telah menunjukkan bahwa model pembelajaran soft skills terpadu dalam pembelajaran Penjasorkes di Sekolah Menengah Pertama telah memenuhi kategori valid, efektif, dan praktis sehingga tidak perlu lagi diuji cobakan. Hasil rekomendasi dan saransaran untuk revisi selama proses pengembangan telah menghasilkan produk akhir berupa pembelajaran soft skills terpadu dalam pembelajaran Penjasorkes di Sekolah Menengah Pertama.

\section{Kajian Produk Akhir}

Pendidikan Pembelajaran Penjasorkes pada dasarnya bukan hanya pendidikan secara fisik, akan tetetapi juga dapat berfungsi sebagai pendidikan terhadap kondisi psikologis siswa. Namun demikian, masih banyak praktisi pendidikan yang menyelenggarakan pembelajaran Penjasorkes dengan hanya melatih dan menilai siswa berdasarkan kemajuan dan kondisi fisiknya. Pembelajaran Penjasorkes belum memberikan fokus kepada pembinaan terhadap diri siswa secara psikologis. Pelaksanaan pendidikan soft skills dalam pembelajaran Penjasorkes secara terpadu masih dianggap sulit dan membutuhkan waktu tambahan, terutama pada Sekolah Menengah Pertama sehingga tidak dilaksanakan. Pelaksanaan pengembangan soft skills siswa pada Sekolah Menengah Pertama seringkali luput dari perhatian. Selain itu, pengembangan soft skills seringkali masih dianggap sebagai kewajiban dari kegiatan ekstrakurikuler tertentu saja, seperti halnya Pramuka.

Berdasarkan landasan tersebut, sebagai upaya untuk mengembangkan soft skills siswa pada Sekolah Menengah Pertama diperlukan suatu model pembelajaran yang dapat mengintegrasikan soft skills secara terpadu dalam pembelajaran Penjasorkes. Model pembelajaran yang dikembangkan adalah model pembelajaran soft skills terpadu. Dalam hal ini, model pembelajaran soft skills terpadu yang dikembangkan adalah model pembelajaran yang dapat diterapkan pada mata pelajaran Penjasorkes secara berkesinambungan. Hal ini telah dibuktikan melalui implementasi model pembelajaran pada saat pelaksanaan penelitian.

Proses pengembangan dilaksanakan melalui beberapa fase, yaitu penelitian pendahuluan untuk mengetahui permasalahan dan konsep-konsep teori yang mendasari pengembangan pembelajaran soft skills terpadu, fase 
desain, dan fase realisasi atau konstruksi produk. Fase-fase ini menghasilkan sebuah draf awal model pembelajaran dalam pembelajaran Penjasorkes di Sekolah Menengah Pertama. Draf awal kemudian dievaluasi melalui FGD, uji coba, dan implementasi produk. Tahapantahapan tersebut menghasilkan draf akhir pembelajaran soft skills terpadu dalam pembelajaran Penjasorkes di Sekolah Menengah Pertama yang memenuhi kategori valid, efektif, dan praktis. Tahap implementasi sekaligus menjadi tindakan sosialisasi terhadap hasil pengembangan sehingga produk diharapkan sudah dapat diterapkan di sekolah. Hasil akhir dari produk pengembangan ini adalah model pembelajaran soft skills terpadu dalam pembelajaran Penjasorkes di Sekolah Menengah Pertama dalam bentuk buku panduan pembelajaran, serta perangkat instrumen penilaian pembelajaran dan perangkat penilaian output pembelajaran.

Ada beberapa hal yang harus menjadi perhatian dan pandangan guru dalam menerapkan pembelajaran soft skills terpadu dalam pembelajaran Penjasorkes. Pertama, guru perlu menyadari bahwa pembelajaran Penjasorkes dapat melatih kepekaan rasa siswa. Kegiatannya pembelajaran Penjasorkes yang melibatkan anak dalam kelompok kecil maupun besar merupakan wahana yang tepat untuk berkomunikasi dan bergaul dalam lingkup sosial. Dalam kehidupan sosial, setiap individu akan belajar untuk bertanggung jawab melaksanakan peranannya sebagai anggota masyarakat. Di dalam masyarakat banyak norma yang harus ditaati dan aturan main yang melandasinya. Melalui pembelajaran Penjasorkes, norma dan aturan juga dipelajari, dihayati, dan diamalkan. Untuk dapat berperan aktif, siswa juga akan menyadari bahwa ia dan kelompoknya harus menguasai beberapa keterampilan yang diperlukan. Kegiatan pembelajaran Penjasorkes sudah seharusnya dapat dimanfaatkan sebagai ajang nyata untuk melatih keterampilan-keterampilan hidup (life skill), agar seseorang dapat hidup berguna dalam masyarakat. Keterampilan yang dipelajari bukan hanya keterampilan gerak dan fisik semata, melainkan terkait pula dengan keterampilan hidup.

Faktor kedua, guru perlu menyadari bahwa pembelajaran Penjasorkes dapat mengembangkan keterampilan sosial siswa. Kecerdasan emosional atau keterampilan hidup bermasyarakat sangat mementingkan kemampuan pengendalian diri. Dengan kemampuan ini seseorang bisa berhasil mengatasi masalah dengan kerugian sekecil mungkin. Siswa-siswa yang rendah kemampuan pengendalian dirinya biasanya ingin memecahkan masalah dengan kekerasan dan tidak merasa ragu untuk melanggar berbagai ketentuan. Penjasorkes menyediakan pengalaman nyata untuk melatih keterampilan mengendalikan diri, membina ketekunan, dan motivasi diri. Hal ini dapat diperkuat lagi jika proses pembelajaran direncanakan sebaik-baiknya. Setiap adegan pembelajaran dalam permainan dalam pembelajaran soft skills terpadu dapat dijadikan arena dialog dan perenungan tentang apa sisi baik-buruknya suatu keputusan sehingga cara ini merupakan cara pembinaan moral yang efektif. Guru harus memanfaatkan setiap langkah pembelajaran untuk mengembangkan keterampilan sosial siswa. Sebagai contoh, jika dalam sebuah proses pembelajaran Penjasorkes terjadi pertengkaran atau perdebatan antara dua orang siswa, guru bisa segera menghentikan kegiatan seluruh kelas dan mengundang mereka untuk membicarakannya. Sebabsebab pertengkaran dan perdebatan diteliti dan guru memancing pendapat siswa-siswa tentang apa perlunya bertengkar, selain itu siswa juga diajak untuk mencari pemecahan yang paling baik untuk kedua belah pihak.

Demikian juga dalam setiap adegan proses pembelajaran soft skills terpadu yang memerlukan kesiapan mentaati peraturan permainan. Di samping guru mempertanyakan pentingnya peraturan untuk ditaati, guru dapat juga mengundang siswa untuk melihat berbagai konsekuensinya jika peraturan itu dilanggar. Lalu guru dapat menanyakan pendapat siswa tentang tujuan permainan. Misalnya guru bertanya: "Apakah memenangkan pertandingan dengan segala cara bisa dibenarkan?", "Apakah kalah dalam suatu permainan benarbenar merugikan?" bahkan lebih jauh lagi mungkin guru bisa memilih topik di luar kejadian yang siswa alami sendiri seperti halnya yang dilaksanakan dalam pembelajaran tematik, misalnya topik tentang tawuran antarpelajar dari sekolah yang berbeda. Topik ini menarik untuk dibicarakan dari sisi moral serta akibatnya terhadap kehidupan bermasyarakat.

Faktor ketiga, guru perlu memahami bahwa melalui pembelajaran Penjasorkes, kepercayaan diri dan citra diri (self esteem) 
siswa akan berkembang. Secara umum citra diri diartikan sebagai cara untuk menilai diri sendiri. Citra diri ini merupakan dasar untuk perkembangan kepribadian anak. Dengan citra diri yang baik, seseorang merasa aman dan berkeinginan untuk mengeksplorasi dunia. Seseorang dengan citra diri yang baik akan mau dan mampu mengambil resiko, berani berkomunikasi dengan teman dan orang lain, serta mampu menanggulangi stress. Cara membina citra diri ini tidak cukup hanya dengan selalu berucap "saya pasti bisa" atau " saya paling bagus". Tetetapi perlu dinyatakan dalam usaha dan pembiasan perilaku. Dalam hal inilah Penjasorkes perlu menyediakan kesempatan pada siswa untuk membuktikannya. Ketika siswa berhasil mempelajari berbagai keterampilan gerak dan kemampuan tubuhnya, perasaan positif akan berkembang dan siswa merasa optimis atau mampu untuk berbuat sesuatu. Dengan perasaan tersebut, siswa akan merasa bahwa dirinya memiliki kemampuan yang baik dan pada gilirannya akan mempengaruhi pula kualitas usahanya di lain waktu, agar sama seperti yang dicitrakannya. Bila siswa merasa gagal sebelum berusaha, keadaan ini disebut perasaan negatif, lawan dari perasaan positif.

\section{Keterbatasan Penelitian}

Beberapa Beberapa faktor yang menjadi keterbatasan dalam pelaksanaan penelitian ini adalah sebagai berikut; 1) Penelitian ini dilaksanakan dengan melibatkan 4 Sekolah Menengah Pertama yang terdapat di Kota Yogyakarta, yaitu SMP 2, SMP 3, SMP 5, dan SMP 7. Keterbatasan lokasi penelitian dapat mengakibatkan hasil penelitian belum dapat digeneralisasi pada populasi lain yang memiliki karakteristik berbeda dengan lokasi penelitian; 2) Soft skills yang dikembangkan hanya terbatas pada 7 soft skills yang dapat diterapkan dalam pembelajaran Penjasorkes pada Sekolah Menengah Pertama. Oleh karena itu, diharapkan ada pengembangan lebih lanjut dengan mengembangkan soft skills lainnya.

\section{SIMPULAN DAN SARAN}

\section{Simpulan}

Hasil penelitian menunjukkan bahwa:

(1) Pengembangan model pembelajaran soft skills terpadu dalam pembelajaran Penjasorkes di Sekolah Menengah Pertama diawali dengan tahap pendahuluan, tahap pengembangan, dan tahap evaluasi. Pengembangan model menghasilkan perangkat model berupa buku panduan model pembelajaran, perangkat penilaian, dan instrumen pengembangan model pembelajaran untuk mengembangkan soft skills kemampuan berkomunikasi, kemampuan berorganisasi, kepemimpinan, logika, upaya, bekerja sama, dan etika. (2) Model pembelajaran soft skills terpadu dalam pembelajaran Penjasorkes di Sekolah Menengah Pertama menunjukkan tingkat keterlaksanaan yang tergolong sangat baik, memenuhi kriteria valid, sangat efektif, dan sangat praktis. (3) Model pembelajaran Soft Skills Terpadu dalam pembelajaran Penjasorkes di Sekolah Menengah Pertama mampu mengembangkan soft skills yang dimiliki siswa.

\section{Saran Pemanfaatan Produk}

Peneliti memberikan beberapa saran pemanfaatan untuk peningkatan kualitas pembelajaran soft skills terpadu dalam pembelajaran Penjasorkes di Sekolah Menengah Pertama, yaitu: (1) diharapkan pada guru dan praktisi pendidikan lainnya untuk menerapkan model pembelajaran soft skill terpadu dalam pembelajaran Penjasorkes di Sekolah Menengah Pertama, (2) guru di Sekolah Menengah Pertama agar menggunakan model pembelajaran soft skill terpadu dalam pembelajaran Penjasorkes di Sekolah Menengah Pertama sehingga siswa dapat meningkatkan penguasaan soft skills. Dalam hal ini, soft skills yang diterapkan guru tidak dibatasi pada soft skills yang digunakan dalam penelitian ini saja, akan tetapi dapat dikembangkan lebih banyak lagi, dan (3) dalam melaksanakan penerapan model pembelajaran soft skill terpadu pada pembelajaran Penjasorkes di Sekolah Menengah Pertama, guru perlu mempelajari dan memahami buku pedoman pembelajaran dan evaluasi yang merupakan bagian dari pengembangan produk model pembelajaran soft skill terpadu dalam pembelajaran Penjasorkes di sekolah menengah pertama secara seksama. Hal ini perlu dilakukan agar guru benar-benar memahami cara penerapan pembelajaran soft skill terpadu dalam mata pelajaran Penjasorkes. 


\section{DAFTAR PUSTAKA}

Dewantara, K.H. (1967). Kebudajaan. Yogjakarta: Madjelis Luhur Persatuan Taman Siswa.

Gall, M. D.; Gall, J. P.; \& Borg, W. R. (2003). Educational research: an introduction. Boston: Allyn \& Bacon.

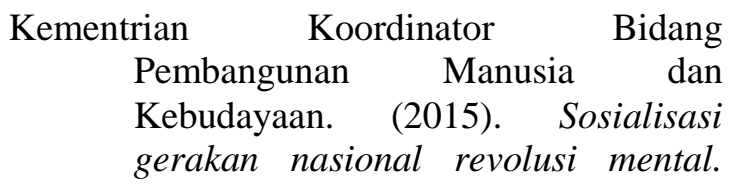

Jakarta: Kementrian Koordinator Bidang Pembangunan Manusia dan Kebudayaan.

Kristjansson, K. (2015). Aristotelian character education. New York: Routledge.

Schulz, B. (2008). The importance of soft skills: education beyond academic knowledge. Journal of language and communication, June 2008, p. 146154. 